\title{
Anticipating Permanent Persuader in Vivek Shanbhag's Ghachar Ghochar
}

\author{
Tara Lal Shrestha, $\mathbf{P h D}^{1}$
}

Email: shresthatara@gmail.com

Received: November 09, 2020; Revised \& Accepted: December 11, 2020; Published: February18, 2021 (C) Copyright: Shrestha (2021).

\begin{abstract}
Role of intellectual is often a crucial as well as controversial issue in academics and activism when an intellectual as a permanent persuader is getting more meager amidst the dominance of consumerist culture and collective crisis of the subaltern. While reading Vivek Shanbhag's novella Ghachar Ghochar, translated from the Kannada into English by Srinath Perur, an affirmation of intellectual's role as a permanent persuader echoes time and again. The protagonist (unnamed narrator) is helpless, who neither could escape from collective crisis of his family nor play any role against the mounting antagonistic condition. He keeps on watching his family crisis with the thought 'it's not we who controls money, it's the money that controls us. 'In the era of proliferation of the hegemony of consumerist culture, as the novella depicts, both the oppressors and oppressed are lingering in limbo beyond the rescue zone anticipating permanent persuader.
\end{abstract}

Key words: Consumer culture, collective crisis, permanent persuader.

\section{INTRODUCTION}

Each individual crisis is associated to collective crisis. Moreover, subalterns are more subtly dominated and subordinated by layers of hegemony. They are more muted in dominant history. Intellectuals have to play role to rescue them from layers of hegemony. Subaltern studies are a methodological tool as well as space of hope to the subalterns to speak. Intellectuals use subaltern studies as a space to speak for the subalterns in the era of the decadence of class studies. Vivek Shanbhag's Ghachar Ghochar (2015) unearths the core essence of the consumerist world. The novella affirms, as an urge of the current times, the need of permanent persuader in the world where/when triumphalism of consumerist capitalism has superimposed the common human values. The dominance of consumerist culture has created predicament of humanity preserved for centuries persisted from the long history of human civilization. An individual's autonomous subjectivity is often obstructed and long preserved human values come

\footnotetext{
${ }^{1}$ Tara Lal Shrestha is a PhD in Subaltern Studies and a Lecturer of Central Department of English, Tribhuvan University. Also a columnist and social activist, Dr. Shrestha has published four research-based books on subaltern issues and edited seven anthologies based on Bhutanese refugee history.
} 
to be superimposed by the hegemony of consumerist culture. A harmonious family, symbolically a human values based community, gets spoiled as in the world realistically articulated in the novella.

Vivek Shanbhag is one of the established novelists in South Asia. He is the author of eight novels and two plays. All of his works have been published to wide acclaim in India, particularly in the South Indian Kannada language. His novella Ghachar Ghochar, translated by Srinath Perur in English from Kannada is the first of his works to appear in English. In an interview Shanbhag says that this novel was inside him growing for several years; the seed of the story was sown three decades ago when he first began working as an engineer when he worked with a few salespeople and the whole family members involved in the seed job. ${ }^{2}$ This came to be the first Kannada novel to be published in the United States. The English translation version of the novel got a wider readership that comes from a different cultural background. It linked to the South Asian current collective crisis to the global crisis.

This research paper presents counter hegemonic essence with an affirmation of permanent persuaders so that layers of hegemony imposed on subaltern groups of people could be minimized for giving hope within hopeless circumstances. Firstly, it introduces the context of growing newer forms of hegemony in the triumphalism of consumerist culture. Secondly, the paper draws insights from Gramscian notion of hegemony with special focus of the need of permanent persuaders. Thirdly, it takes intensive references from Vivek Shanbhag's novella Ghachar Ghochar. Finally, this research paper as the conclusion shows the nexus between individual and collective crisis with an affirmation of permanent persuader.

\section{Counter hegemonic Essence in Vivek Shanbhag's Ghachar Ghochar}

This is the world of money; it is the time of money. Everything is going to be controlled by money. Troubles, piles of troubles, are also created by money. Money has united and disintegrated unified family and community. The novella successfully projects the spirit of the current time of capitalist triumphalism and its consequences. Parul Sehgalkeenly points out with the beginning sentence in the New York Times review, "Troubles - like ants - seldom walk alone" when the unnamed narrator says, "it's not we who control money, it's the money that controls us."In the words of Dan Elnav, "a poor family, who switch from financial to moral bankruptcy when they suddenly come into money" and all members are helpless in the absence of permanent persuaders. In the novella the family in economically emerging India that represents larger communities is heading towards apocalyptic world of capitalism giving up shared values. Everyone in the family look helpless even when an urgent action is essentially required to settle the issues of moral decay. This vacuum represented in the novel is really remarkable because when we think great novels since Salman Rushdie that set a certain tone with Midnight's Children, as book review of Independent states, Arundhati Roy's The God of Small Things, etc. written in English, now this novel has shaken up the status quo. The fear of

\footnotetext{
${ }^{2}$ https:/www.bookbrowse.com/author_interviews/full/index.cfm/author_number/2910/vivek-shanbhag
} 
falling in the world of capitalist globalization, as Maurren Corrign points out, makes the most of the characters muted individuals.

The opening chapter itself demonstrates, in the words of Deborah Smith, "precise observations, accumulation of detail, narrative progression by way of oblique tangents... with Srinath Perur's excellent translation." The novella opens in a Bangalore coffee shop whose name has not been changed in a hundred years. The narrator is sitting at Coffee House longer than usual before totally disturbed with the blow within and outside. As Eileen Battersby writes, "Something appalling may have happened. A sense of dread has unsettled the narrator...." There are few people around and directly in his line of sight is a young woman in a blue T-shirt scribing something in a notebook. There are two books, a glass of water and a coffee cup in front of her on the table. She looks sitting there at least thrice a week. Sometimes there's a young man who joins her for a coffee and they leave together. The man comes that day too but the narrator sees her holding his collar and the other is slapping him across the face. She releases his collar and "throws a book at him, then another, all the while screaming abuses that implicate all men" (4). She pauses a while - her eyes darting over the table in rage as if looking for something else to attack him with and she takes the glass of water and flings it at him, her target misses and the glass shatters against the wall. She's surprisingly calm after he's gone away. From the very first scene - the first page to the end - the novella deploys local-looking global issues - the theme which is domestic but associated to national and global networks. It is a novella in simple sentences with many sides as the oracular waiter Vincent explains, the episode of the dispute of braking up at Coffee House that people speculate the man has been unfaithful, "Sir - one story, many sides" (4).

There are women characters getting lost one after another as ants are killed whereas their aspirations count significant in social wellbeing. One can see a serious lacking of broader solidarity among these women, the subalterns. Whenever they get subaltern consciousness and show resistance, they are lost unknown of their whereabouts. There is no one in search of the root of the suffering of the subalterns; the destitute of dissent subaltern consciousness looks as if it is a common plight as killing ants intentionally or accidently. Antonio Gramsci rightly asserts, "The history of subaltern social groups is necessarily fragmented and episodic... Subaltern groups are always subject to the activity of ruling groups, even when they rebel and rise up: only 'permanent' victory breaks their subordination, and that not immediately" (54-55). Gramsci unhopefully further asserts that in reality even when they appear triumphant, the subaltern groups are merely anxious to defend themselves, for instance the French Revolution at least up to 1830. There are many instances like French Revolution all around the world, including Nepalese and Indian history, where in reality even when they appeared triumphant, the subaltern groups failed to defend themselves. How is the reality of the gender subaltern who is, in the words of Ranjit Guha, dominated and subordinated in terms of many layers, i.e. gender, class, caste, ethnicity, region, position, post, cultural and social taboos, etc. 
Chitra, an activist lady, to whom the unnamed narrator used to join on most afternoons at a table in the very Coffee House. She would tell him about her day fighting against domestic violence that could make him more muted, feeling vaguely guilty? Where has she been lost after that day presenting as if whatever there was between them get vanished as a insignificant event? Her pride could never allow her to come after him? Or, she doomed as other women, poor daughter-in-law and the criminals escaped easily? Or, she is fighting against men and women who killed daughter-in-laws as a common episode like killing ants? That day, the last day of their meeting, she told him about the woman who was kicked out of the house in the middle of night by her mother-in-law; she vowed to put the husband and mother-in-law inside of a jail; then they never saw each other again, because she did not come back again. What happed to Chitra is unknown in rest of the novella. It is the common plight of the subaltern in the absence of permanent persuader, who really plays role to represent from political level in Gramscian notion as the true responsibility of the intellectuals.

Sushasini, a naïve beloved of Chikkappa is more helpless. Once, "a couple of weeks ago", there was a commotion when she came up to the house on a pale green sari with a red border. "Nothing in her bearing suggested she was a disreputable woman" (12). It was Sunday, at around nine in the morning. She was waiting awhile some distance away from the house, hopping to speak to Venkatachala, the narrator's Chikkappa (uncle) - the family's sole earning member, unmarried. His mother soon saw her from the kitchen window, then others. It was the half hour or so the woman stood there, glancing from time to time at the house. She is devoted to Chikkappa but Amma and Malati, his elder sister, mistreated her with words, "Get out! Get Out, you whore!" (15). No male members - Appa, Chikkappa and the narrator - stopped Amma and Malati to abuse her. Anita, the narrator's wife didn't come out to support Amma and Malati. Sushasini had not abused them; she had no intention to pick a fight. They tore into her with such vengeance that she collapsed to the ground, sobbing. She was sure that Chikkappa would come to her aid, but he didn't. She called out in a hoarse voice: "Venka...Venka...Come outside. It's me, your Tuvvi" (16). She exposed those private names to public; however, there was no trace of Chikkappa. Amma threw the hot case with Massor dal curry, Chikkappa's best food that she was carrying and that formed a thick puddle on the ground. But, he didn't come out. Sushasini walked briskly out of the yard and was soon out of sight. Readers didn't see her too after that. Nobody knows, what happened to Sushasini?

Anita, the new bride, the wife of the narrator, didn't participate in the events of that morning - in the Sushasini episode. Amma and Malati noticed Anita's dissent, as "it's an unwritten rule that all members come to the family's aid when it is threatened" (17). In the words of the narrator, "Anita had broken that rule. She should not have" (17). Actually Anita is the key subversive subaltern character - a salutary new member of the house. She didn't participate in the episode to support to Amma and Malati - it was against the unwritten rule of the house because she felt that an injustice had been done to the woman. Amma and Malati were furious and so was Anita. 
When the 'drama' staged to drive an innocent beloved of Chikkappa was over, everyone is inside their room. The narrator notices Anita glaring at him and he justifies, "I didn't abuse her" (19). Anita's reply was really bold, "It's enough for a man to simply stand there and watch. It's worse than shouting at her yourself. How could you all pounce on that woman without knowing a thing about her? Is it her fault alone?" (19). It was a bold dialogue a new bride could make in Indian society. He neither could refute her, nor could tell her that Chikkappa must be protected at all costs. The more Anita gets truths within truths about the family, the more she enters into the labyrinth of life threats. The narrator, her husband, himself is not sure that she could survive; her words and actions send a chill through him - surely, she is creating a big threat to the whole family members. The narrator is encountering blood images one after another from Anita; she is hallucinating that there is blood in his hands. There is everything, he knows, available at home to kill her easily as a simple suicide. It is not sure, at the end, what happened to Anita, too. She has not returned from Hyderabad; something happened during her journey or at home is not sure. The narrator, her husband, neither could protect her nor could have courage to face the reality.

The novella not only depicts the capitalist crisis of modern India, it also deploys multitude sense of internal crisis within individual, either within new elites or subaltern, in the absence of permanent persuaders. Soliloquies and confessional sense of sensibilities fall upon readers and flow away. One can carry on calculating their actions and recall associations; their internal crisis exists as a systemic failure as if it is common plight in capitalist culture rampantly spread throughout the world. A serious reader might plunge into way out of the problem.

There are other victims too, like Manjunath's wife, Suniti and some others characters who have been killed like an ant and the criminals are living free life without sense of fear and guilty. Chitra, Sushasini and Anita are lost in the labyrinth of death threats. At the core, actually we all are under the big machine floating through internal crisis. "We are in internal crisis because we have our defining story badly wrong”, says David C. Korten, "Seduced by a fabricated Sacred Money and Market story, we live in indentured service to money-seeking corporate robots and relate to Earth as if it were a dead rock for sale....An authentic Sacred Life and Living Earth story is emerging; it has ancient roots in indigenous wisdom; if embraced, it changes everything."

In the era of triumphalism of capitalism Vivek Shanbhag's Ghachor Ghochar has been appeared as one of the avatars of affirming current predicament of the subaltern in the contexts where permanent persuaders are decreasing. The interesting point to be noted is that it is a novella translated from Kannada by Sprinath Perur and published by HarperCollins. And, it came to our hands in Nepal floating from the Western metropolis through India. This is the predicament of Asian intellectuals (where import-export imbalance of texts as well is too wide)and real picture of print capitalism in there era of globalization. The predicament in the novella plunges in-between the transition and transformation - that is, traditional eastern values and complex western capitalist life styles. The conflict is of multitude - internal versus external 
states, communal versus individual values, and cooperative versus calculative cultures. The title of the novella - Ghachor Ghochar - itself is an enigmatic stuff. And, the story moves around a small family from simpler to a complex broader theme in the form of beyond rescue, ghachor ghochar- the irreversible impact of capitalism on innocent individuals.

The protagonist is surely Anita, a new bride, despite the fact that she holds little space in the novella. She is important character as a truth teller - innovator - sympathizer - subversive subject. The unnamed narrator - the lethargic husband of Anita - looks innocent and alienated in first person, whounfolds fabrics of his family history of transition and transformation fabricated with fragmented history of domesticity; the internal state of his psyche is as eloquent as external events he plunges into. His life is a life of ghachor ghochar-a journey to nowhere beyond recovery. Neither he could live a blissful life, nor can escape of it. He spends hours - up to 30 hours - in an old café. He is confined within his family stories. Like a baby king, he is inbetween the states of innocence and experience. Even after Anita comes in his life as a bride, he is beyond state of rescue zone. He is the narrator, but looses authority as protagonist. He is a passive witness of cruel capitalist violence and poor persuader of predicament rather than permanent persuader of the liberation of the subaltern.

The narrator couldn't put up a fight when the family began efforts to search girls get him married. None of his attempt at romance before had gone anywhere. It was only Chitra with whom he'd got as far as having long conversations, and that too was over. His elder sister Malati's marriage had ended badly and it was her fault of running her conjugal life. When his mother received word about the daughter of a college lecturer in Hyderabad (Anita)through a friend Sripati and he got two photographs of the girl - thick eyebrows, broad shoulders and something hypnotic - one of the photographs would drive him wild - the slightly upturned nose, the swell of her breasts discernible through the fabric of her dupatta. He reveals his subconscious with the words, "I suppose Chitra was right when she'd say men were incapable of seeing beyond the bodies of women" (69). Anita comes to his life formally. She is so simple but so rich in manner and thoughts. He is really rich economically and too poor in terms ethical values.

Three days after the wedding, they had left for Ooty for their honeymoon. The wait had driven him half mad. When he had reached to the hotel, he had closed the hotel door and pounced on her. He had tore off her sweater, her sari, her blouse and yanks at her petticoat's drawstring but only managed to jam it up. His impatient hands could not get anywhere with the stuck knot. She had tried too, but to no avail. "Tchah", she had said, "this string has become all ghacharghochar...wait" (74). He had been amused of the words 'ghachar ghochar' called to petticoat string. He had never heard the expression before.

There are only four people in this world who know what 'ghachor ghochhar' means Anita, her parents and her brother. In her childhood her brother had used this expression when the kite strings had become so entangled and being unable to separate and he had shouted, "This has all become ghachar ghochar!" (75). While they were lying on honeymoon bed catching their breaths, he asks her, "What was that you called the petticoat string?" and she giggled, "Ghachor 
ghochar" (74). She repeated, 'ghachar ghochar' and her eyes shining. But from that very moment her days of sorrow began. She found that her husband has a jobless job - a job without duty. He was getting good sum for no toil. He was killing ants as senseless violence. He was in endless leave and a big sum was being deposited regularly in his account.

That is not only useless income; it is also an ethical crime to Anita. He is a director of the family company - Sona Masala - just a paper director, not executive post at all. His visiting card is just reprinted every year. The central figure of his household is his chikkapa, Venkatachala, his father's younger brother and the family's sole earning member. Coming Anita as a bride is a source of much turmoil at his home. She insists, "Tell me the truth. What exactly is your work?" The more she is investigative, the more turmoil increases at home. She says, "I can survive on very little, but I want you to have a respectable job, whatever it is." But he is helpless - the leisure class mentality has transformed him into a useless man without any experience or skill to get a job.

Anita is disillusioned to all the expensive gifts she persistently got during her honeymoon period. Nobody knew how the factory was running. He is not fit at the factory, so is the father. Anita knows that only Appa (the father) is spiritually alive member at home, who believes, "Wealth shouldn't strike suddenly like a vegetation, but instead grow gradually like a tree" (21). Appa as well is weak to act according to his philosophy. He is mocked as misfit to current time. His brother Chikkapa addresses Appa with the nickname 'coffee king' and indicates how much outdated he is in business. Chikkapa has learnt to kill people safely and all family members don't mind him except Appa. They take killing people as if it is a normal event like killing ants. Upset Appa asks, "You're all talking as if it's right to kill someone when it suits us." Chikkappa sighs, "Coffee king is living in another age; these things are not as big a deal today" (112). At the end Appa is speechless, who could do nothing except departs from the dining table towards his room. There is just silence. Appa including other family members are caught in a trap of their own making with no obvious way out.

Smarter Anita, who has already explored the corrupt reality -disillusioned and beyond the state of adjustment - leaves for her parents' home by taking second-class train ticket; she her husband's request to get a plane ticket to fly to her parents' home. The three women are often too much to him, but he is unable to settle the issue. He rather starts "hurrying to leave the house before it erupts" (61) and spends time up to 30 hours at the old café with the Vincent - an allknowing waiter. He has nothing within him except the haunting memories.

The family was happy till they were in a small house in Baglore. Appa (the father) would work in a factory as sales man. His little earning was a source of bliss. Whole family members struggled together. They would share each sort of feeling to each other - all sorrows and happiness were shared. Suddenly, Appa lost the job and the economic crisis forced them to start a spice factory. Chikkapa led the company with fifty percent share to Appa. So soon they were successful. That success turnedas deeply unsettling knots - the knot that could not be untied. The 
sudden economic success turns cruel - an ordinary life of a family turns into extraordinarily brutal.

The author Vivek Shanbhag and his good wishers are right - it's true what they say - it's not we who control money; it's the money that controls us. Someone is weak because there is no money. Someone else is powerful just because they have money. But, the powerful upstarts like the unnamed narrator - a sensitive young man - is really hollow in interiority due to the money. They have nothing except the money. All the family members of the narrator, the more they gain material comforts the more they are alienated and internally hollow. The communal conscience and ethical space exist no more, where Anita - the new bride - could not adjust; nor can the narrator act to create an ethically adjustable space to his bride. The three women - Anita, Amma and Maliti - are enough to him. He is convinced that 'the words of women that deeply wound other women when Amma and Malati use so violent words to Susasini, the woman who loves Chikkapa. They drove her away ruthlessly - Amma abused her saying, 'beggar...whore!' It is too much for Anita, who didn't come out to defend Amma and Malati. Anita is more offended when she saw her husband was watching violence - an innocent woman was beaten, her rahar curry for Chikkapa spoiled - not speaking at all means becoming agent of injustice. Anita begins to compare the house as brothel; the environment of the house was too much for her, whois from a simple salaried teacher family; she is too simple to adjust in business family, where not only killing the ants, killing people is normal when suits to their business. She wishes women should care to women but Amma and Malati are really ruthlessly criminalized and ethically dead. So, there is blood even in the hands of innocent-looking narrator.

"Today", as John Bellamy Foster and Hannah Holleman writes, "the concept of 'financialization' stands for the shift in the centre of gravity of the capitalist economy from production to finance... a major secular shift toward finance in capitalism as a whole, transcending mere business cycle swings, is unique to the last few decades" (191). As they claim, led by the US, a financial explosion first emerged in the 1970s and 1980s and eventually became a globalized phenomenon has significantly altered not only the structure of ruling class power, it also has altered the life styles of common people of Asia as presented unfortunately in the novella Ghacchar Ghochhar. The novella moves between the past and present - the communal tradition and crisis of corrupt capitalism.

The quest is how to change their stories to change their future as Korten appeals from the metropolis of capitalism. It is not a crisis of an individual - not a crisis extended up to a family; it's a collective crisis in the era of globalization. The more interesting thing is that the novel begins at a Coffee House. The first sentence goes on, "Vincent is a waiter at Coffee House" (1). It is an old coffee house and the name hasn't changed in a hundred years, even if the business has. The walls are paneled in wood to shoulder height. The narrator and his family are not able to maintain their old values. But, old photographs hang on the sturdy square pillars in the center of the room, showing just how beautiful that city was a century ago - somehow Coffee House still manages to belong to that world. That day the narrator has been sitting in Coffee House longer 
than ever before. It is the same table at which Chitra and he used to meet. He watches 'one story, many sides'-a couple is breaking up - the man has been unfaithful. He has already witness a lot of real domestic violence stories through Chitra as she was working for a woman's welfare organization and the things she said about men he took as applying to himself. He recalls, "I could only sit there mute, feeling vaguely guilty" (6).

Chitra would keep on asking, 'How could you break her arm simply because the tea was not to your taste?' Or, 'Do you kill your wife because she forgot to leave the key with the neighbor?' He knew that tea should not lead to a broken arm, or a forgotten key to a murder. There was really nothing to their relationship, he supposes, "certainly nothing physical" (7). There was no room for anything other than her anger - no tenderness between them. Last time she had told him about a woman who had been tortured out of her house in the middle of the night by her mother-in-law. Her words went on:

While the woman shivered outside, her husband and his parents and sister all slept warm in their blankets. She'd sat there, hearing her husband's snores through the window. At dawn she hid her shame from the milkman by pretending she was waiting for the milk. Chitra's voice grew in shrillness as she described the woman's plight. (7)

Before Anita came to his life as a bride, Chitra was there - just as a friend. He recalls his past days spent with Chitra. As he sits there in Coffee House that day, his mind is more disturbed than usual. He recalls the events happened to Sushasini. How her mother and sister had beaten her and how silent witness role he had played then. He recalls earlier phase of his household when his father is just a salesman. Appa's work was whole family's work - his sweet relation with family members, collective sharing of pains and happiness; shifting situations get reflected in front of him. More is Anita, his predicament of inability to act according to the wishes of her. The honeymoon - the sharing - knowing Anita is so much important to him to be transformed but looks beyond psychiatric help.

The culture of the parents' home of Anita is convincing but beyond applicable at his home. Everyone gets up earlier. Her father has a very sensitive stomach, which he protected by never eating or drinking outside home other than the occasional coffee. In her words, "Appa would leave for university before we left for school. He'd spend an hour or so in the library before going to his department. When his classes for the day were done, he'd spend some more time in the library, then return home by seven in the evening" (78). Things are too different to Anita. All are cruel except Appa - where violence very normal - a woman is against another woman. Sushasini is nothing to Anita, but she was something to someone. She didn't like how two women 'chased her off like a stray dog without even listening to her' and the males kept muted witness. Anita boldly argues, "If women don't support other women, who will?" (95). Chikkappa had done something wrong to Sushasini - a mistake - so he had no courage to stand by her. Anita wanted to give justice to Sushasini. In Anita's words, "There is no smoke without fire" (97). Amma and Malati wanted to ensure that Chikkappa remains unmarried. They can't stand the thought of anyone else, in Anita's words, entering this house and challenging their 
authority. During the quarrel at dining table, the narrator is helpless. In his words, they had so far managed to keep Chikkappa happy with nothing unpleasant ever falling on his years. He thinks, "The well-being of any household rests on selective acts of blindness and deafness. Anita had outdone herself when it came to suicidal forthrightness. It looked like she wanted to destroy all of us along with herself" (97). Malati said, "Finish your launch and leave with your tail between your legs" (97). What was he to do? He is in-between in these women's side. The mother was first time defeated but he could not dispute what she was saying either. Anita seemed satisfied with her work and ate without hurry and went to her room.

How hard to everyone to face Anita at home. So, she is to leave that evening for Hydarabad for a week. He just hopes she would manage to leave the house without any further calamity. She keeps on muttering as she packs:

[....] Would you have kept quite if that happened to a woman from your family? The only decent person in this house is your father but the rest of you behave like he's insane... One day I should go to the police and tell them everything I know about this family's affairs...Let the dirt come out into the open. Maybe I should go today itself on my way to the railway station.... (98)

These last words sent a chill through him. The word 'police' has always filled them a strange fear. Chitra was one of them. The same story with Anita - he thought it best not to say anything and kept his eyes closed. Anita goes to her parents' home by second-class train ticket. There is festive moment at his home. He had betrayed Anita. There are news and rumors of women killed - Manjunath's wife...others too murdered and murderers escaped - they are talking about good plan to killing... 'the weapon of murder is crucial in murder cases that go to court; so the best way to protect oneself is to not have a weapon at all' (111). Appa is upset with their family talks - it's totally criminal. But according to Chikkappa, killing people is practically collective responsibility of businessmen. But, Appa is a voiceless, powerless subaltern - so is the son, the narrator, as usual he says nothing, but his very silence implicated him. Appa gets up and leaves; then the rest of them too, one by one.

The narrator as usual rushes to Coffee House in some agitation. As Vincent places his coffee on the table, he says to him distractedly that he hoped everyone at home was well. Vincent nods, and with a faint smile says, "Blood is thicker than water, isn't it, sir?" (113). He begins to shiver at the mention of blood, and he thinks, "Whatever the meaning of saying, why should he bring up blood at a time like this?" (113). He is at least kind enough to pretend not to notice his discomfort and Vincent goes away without speaking another word. It was Tuesday, that day. Anita hasn't called since she left. Going by the ticket he'd booked for her, she should have been back last afternoon. He is really upset that is what his expression shows:

I haven't returned home since I left yesterday morning. Haven't been able to summon the courage. Slept on the sofa in my room at the warehouse. Roamed here and there all morning, and now I'm at Coffee House. It's imperative I speak to Vincent. I'm telling myself everything is fine but can't convince myself.(113) 
"Why hasn't Anita called?" He thinks that she would have if she had arrived. No one from home has called either. Chikkappa saw him that morning but said nothing. He is just getting wrong number. There are question marks. His mind is in a whirl. Maybe Anita hasn't returned; or, "maybe she's back and hasn't called because she's still mad at him" (114). His further patterns of thought are more shocking:

Could she have had an accident on her way from the railway station? What if a lorry slammed into her as she got out of the auto-rickshaw outside our home? What if she's killed herself? There's everything she might need at home. A roll of rope, electric current, sleeping pills. A tall building not too far away. Two women at home goad her what agent of death is as discreet as words? (114)

It's enough of that madness. He is ready to return home. The glass of water shatters in his hand. Vincent seats him at the next table. He sets there trying to compose himself, sipping the coffee at intervals with some determination. Vincent says, "Sir, you may want to wash your hand. There's blood on it" (115). He freezes, "What's happening? What have I become entangled in?" (115). He feels, "there must be some way out of all this... The words rush into his head of their own accord: ghachar ghochar".

\section{CONCLUSION}

The key concern of this paper is to affirm counter hegemonic discourse for fostering subaltern consciousness that is the revolutionary consciousness of the oppressed. This researcher took insights from Gramcian approach with special focus on the need of intellectual's role as permanent persuader. It presents how Shanbhag's Ghachar Ghochar intersects individual to collective crisis. The hegemony of consumerist culture has forced a happy family to collective crisis. This novel unfolds how a simple family is moving towards the state beyond rescue zone. The world of the novella and the predicament of the characters look moving on towards the dissolution, where all the characters - oppressors or oppressed -are under the hegemony of the corrupt culture of capitalism. They look beyond healing zone of collective crisis. The characters having subaltern consciousness of resistance get lost within the peripheries of so-called civilized modern cities, where the bridegroom is unable to protect his beloved bride from his own family members. His individual crisis persists towards collective crisis. The role of intellectuals as permanent persuaders exists nowhere. The chaotic sense of insecurity of each individual regardless someone is either elite or subaltern - affirms the existence of permanent persuaders as strategic essentialism in the novella so that subaltern-friendly subjectivity and autonomous existence for collective consciousness could be preserved in order to save agency and inner freedom of the oppressed. The finding of this paper is apt to the local as well as global context because the hegemony of money leaves no corner of the world safe. Each individual crisis, as of the protagonist and the narrator of the novel, has been associated to family as well as collective crisis, which anticipate permanent persuaders. 


\section{WORKS CITED}

Battersby, Eileen. "GhacharGhochar: Literary perfection from Indian master". The Irish Times. Assessed, Apr 22, 2017 06:00., https://www.irishtimes.com/culture/books/ ghacharghochar-review-literary-perfection-from-indian-master-1.3054001.

Corrigan, Maureen. A Fretful Vision of Indian Class Anxiety. NPR Review. Assessed, Feb, 16, 2017, https://www.npr.org/2017/02/16/513904303/ghachar-ghochar-presents-a-fretfulvision-of-indian-class-anxiety.

Guha, Ranjit,editor. Subaltern Studies:Writing South Asian History and Society. Vol I., OUP, 1982.

Korten, David C.Change the Story Change the Future: A Living Economy for a Living Earth. Berrett-Koehler, 2015.

Elnav, Dan. "Short Review". Financial Times. Assessed, Apr. 13, 2017,https:/www.ft.com/content/742af76c-1ea0-11e7-a454-ab04428977f9.

Foster, John Bellamy and Hannah Holleman. "The Financialization of the Capitalist Class: Monopoly-Finance Capital and the New Contradictory Relations of Ruling Class Power". Imperialism, Crisis and Class Struggle: The Enduring Verities and Contemporary Face of Capitalism, edited by Henry Veltmeyer, Brill, 2010, pp. 191-201.

Gramsci, Antonio. Selections from the prison Note books, edited and translated by Quintin Hoare and Geoffrey Nowell Smith, Orient Black Swan, 1996.

Sehgal, Parul. “A Great Indian Novel Reaches American Shores”. The New York Times. Apr 6, 2017,https://www.nytimes.com/2017/04/06/books/review/ghachar-ghochar-vivekshanbhag.html.

Shanbhag, Vivek. Ghachar Ghochar, translated by Srinath Perur, Harper Perennial, 2015.

Smith, Deborah. "Ghachar Ghochar - a masterful English-language debut". The Guardians, 27 Apr 2017 12.00 BST, https://www.theguardian.com/books/2017/apr/27/ghachar-ghocharvivek-shanbhag-review.

This Novella Packs a Punch. Independent, 19 April 2017,https://www.independent.co.uk/artsentertainment/books/reviews/ghachar-ghochar-vivek-shanbhag-book-reviewa7690991.html. 